\title{
RELASI SOSIAL MAJELIS MUJAHIDIN DALAM KONSTELASI KEBANGSAAN
}

\section{THE SOCIAL RELATIONS OF MAJELIS MUJAHIDIN IN THE NATIONAL CONSTELLATION}

\author{
Rosidin \\ Balai Penelitian dan Pengembangan Agama Semarang \\ Jl. Untung Suropati Kav. 69-70 Bambankerep, Ngaliyan, Semarang \\ Telp. (024) 7601327 Faks (024) 7611386 \\ Email : nazalnifa@yahoo.co.id
}

Naskah diterima tanggal 4 April 2016. Naskah direvisi tanggal 13 April 2016 Naskah diterima tanggal 3 Juni 2016.

\begin{abstract}
Abstrak
Pasca reformasi 1998 di Indonesia, banyak bermunculan gerakan maupun pemikiran keagamaan yang memainkan peran dominan dalam isu-isu nasional, baik yang bercorak liberal, moderat sampai bercorak radikal. Salah satu gerakan yang muncul adalah Majelis Mujahidin. Penelitian kualitatif deskriptif ini dilakukan dengan metode wawancara, dokumentasi dan observasi. Penelitian ini bertujuan untuk mengetahui (1) bagaimana latar belakang berdiri, (2) relasi dengan masyarakat dan (3) sikap dan pandangan Majelis Mujahidin dalam konstelasi kebangsaan. Hasil penelitian ini adalah: pertama, Majelis Mujahidin di deklarasikan pada penutupan kongres Mujahidin tanggal 7 Agustus 2000 di Yogyakarta. Majelis Mujahidin bersifat aliansi menginginkan penerapan syariat Islam pada lembaga negara Kedua, Majelis Mujahidin terbuka bekerja sama dengan kelompok agama ataupun tokoh-tokoh lain. Ketiga, Majelis Mujahidin memandang kontitusi yang benar adalah seperti dirumuskan pendiri bangsa dengan piagam jakarta di dalamnya. Menyikapi hal ini Majelis Mujahidin membuka cara-cara dialog dalam perjuangannya dengan menawarkan solusi pemecahannya.
\end{abstract}

Kata kunci: Relasi sosial, syariat Islam, konstelasi kebangsaan

\begin{abstract}
The Post-1998 reform in Indonesia, many emerging movements and religious thought which plays a dominant role in national issues, both patterned liberal, moderate also radical patterned. One of the emerging movement is MMI. This descriptive qualitative study conducted by interview, documentation and observation. This study aims to determine (1) how the background standing, (2) relationships with the community and (3) the attitudes of the MMI in the constellation of nationality. The results of this study are: first, MMI declared at the close of the Mujahidin congress dated August 7, 2000 in Yogyakarta. MMI is an alliance desire the implementation of the state agencies. Secondly, MMI is open to cooperate with religious groups or other figures. Third, MMI looked correct constitution is as defined by the nation's founding in Jakarta charter. Then, MMI open dialogue means in their struggle by offering solution to solve them.
\end{abstract}

Key words: social relations, Implentation of Islamic law, the constellation of nationality

\section{PENDAHULUAN}

$\mathrm{I}$ slam merupakan agama rohmatan lil alamin, yang membawa perdamaian, cinta kasih, kemanusiaan, dan menebarkan keselamatan bagi insan sekalian alam. Namun, agama dijelaskan Haedari (2006) kehilangan sentuhan kemanusiaannya ketika berbagai konflik sosial seringkali muncul akibat krisis keagamaan (Rosidin, 2004: 1). Penyebabnya kesenjangan yang cukup dalam antara aspek normativitas dan historisitas dari agama itu sendiri (Abdullah, M. Amin, 2005: xx). Artinya, krisis keagamaan ini muncul disebabkan adanya klaim kebenaran (truth claim) atas tafsir keagamaan yang sepihak serta kuatnya sikap eksklusif dalam beragama. Sikap eksklusif ini berdasarkan pada anggapan (prejudice) bahwa pemahaman keagamaan mereka, baik kelompok maupun individu yang memiliki pemahaman yang paling benar. Sehingga Kurtz (1995) memperjelas bahwa orang di luar pemahaman mereka adalah orang yang salah serta "harus diselamatkan" dengan jalan mengikuti apa yang mereka pahami tentang doktrin ajaran agama tersebut. Dalam gerakannya, kelompok ini seringkali melakukan dengan jalan radikal atau 
tindak kekerasan yang mengatasnamakan Tuhan (Rosidin, 2004: 1).

Selain itu, Islam adalah agama yang menjadi sumber manusia membangun peradabannya menuju tujuan yang di tetapkan oleh Allah. Syekh Abul A'la (1995) menegaskan, hal ini sangat logis dan rasional apabila Islam sejak awal membimbing untuk mewujudkan suatu kehidupan yang sesuai dengan fitrahnya. Artinya, dengan meniti jalan yang ditetapkan oleh Islam manusia akan sanggup dan berhasil meraih kehidupan yang di ridhoi Allah (Amrullah, Baizar: 2009: 1).

Berbagaifenomena melahirkan istilah yang melekat pada penganut ajaran Islam itu sendiri. Istilah fundamentalisme dan radikalisme dalam perspektif Barat maupun orang Indonesia sendiri sering dikaitkan dengan sikap ekstrim, kolot, stagnasi, konservatif, anti-Barat, dan keras dalam mempertahankan ideologi bahkan dengan kekerasan fisik. Sementara dalam perspektif Islam, istilah tersebut berarti tadjid (pembaharuan) berdasarkan pesan moral Alquran dan al-Sunnah (Muhammad Imarah, 1999: 22).

Pasca reformasi 1998 berbagai gerakan muncul ke permukaan. Mereka yang semula bergerak di bawah tanah sampai mereka yang memang sudah terdengar sebelumnya. Suara dan aspirasi disampaikan dalam bentuk aksi demo. Semua meluapkan keinginan kelompoknya untuk dapat eksis dan diakui keberadaannya. Partai politik, pegiat demokrasi, HAM bahkan PSK (pekerja seks komersial) dan LGBT pun tidak ketinggalan ikut ambil bagian beraspirasi. Sebagian masyarakat ataupun kelompok kegamaan prihatin melihat kenyataan ini (Irfan S Awwas (penyunting), 2001: 398).

Salah satu kelompok keagamaan yang berikhtiar memperjuangkan pelaksanaan syariat Islam secara kaffah dalam segala lini kehidupan adalah Majelis Mujahidin. Tulisan ini berusaha mengungkap pertanyaan (1) bagaimana seluk beluk Majelis Mujahidin, (2) bagaimana relasi sosial Majelis Mujahidin dalam kehidupan bermasyarakat, dan (3) bagaimana relasi Majelis Mujahidin dalam kehidupan kebangsaan?

\section{Kerangka Teoritik}

Radikalisme merupakan pemikiran, sikap, dan tindakan keagamaan yang cenderung mengedepankan teks-teks secara skriptual dalam memahami agama. Sikap radikalisme keagamaan ini muncul dilatarbelakangi oleh dua faktor. Pertama, faktor internal, di antara sistem pendidikan dan pola pemahaman agama yang bersifat 'amali yang akan menjadikan agama sebagai sebuah sistem dogma yang absolut dan sebuah kebenaran yang mutlak. Kedua, faktor eksternal, baik faktor politis karena adanya dominasi, sosiologis disebabkan sikap peminggiran terhadap umat Islam, kultural maupun keagamaan (Muin, Abdul, M, dkk, 2007: vi). Pada dasarnya, radikal ditandai dengan empat hal, yaitu: (1) sikap tidak toleran, tidak mau menghargai pendapat dan keyakinan orang lain. (2) sikap fanatik, selalu merasa benar sendiri serta menganggap orang lain salah. (3) sikap eksklusif, membedakan diri dari kebiasaan masyarakat kebanyakan, dan (4) sikap revolusioner, yang cenderung menggunakan kekerasan untuk mencapai tujuan (Abegebriel, Agus M., dkk, 2004: vii). Apapun bentuknya, baik radikalisme, fundamentalisme, maupun terorisme dari gerakan keagamaan hanya akan membuat agama, akan jauh dari watak aslinya sebagai agama rahamatal lil 'alamin serta membuat agama kehilangan tujuannya yang hakiki. Syariat Islam dengan berbagai perangkatnya diturunkan kepada manusia sebagai fondasi kehidupan (maqashid assyariah) melindungi seluruh dimensi kemanusiaan serta memudahkan manusia dalam menjalani kehidupannya dengan cinta damai, jauh dari sikap fundamentalisme, radikalisme maupun terorisme.

Beberapa kajian yang membicarakan radikalisme antara lain Jalaluddin Rahmat dengan buku Psikologi Agama, Said Aqil Siradj dengan Tasawuf Sebagai Kritik Sosial: Mengedepankan Islam Sebagai Inspirasi Bukan Aspirasi, Muchsin Jamil dalam penelitiannya Agama-Agama Baru di Indonesia, dan lainnya. Sedangkan beberapa hasil penelitian yang terkait dengan radikalisme, gerakan keagamaan, dan dialektika Islam tradisional versus Islam puritan, di antaranya: Abdullah Faishol dalam penelitianya: Tuntutan Penerapan Syariat Islam Kelompok-Kelompok Islam Radikal di Surakarta; Muhammad Wildan, Mapping Radical Islamism In Solo: A Study of The Proliferation of Radical Islamism in a Town in Central Java; Fuadudin dalam penelitiannya yang berjudul Melacak Nalar Radikal; Kasus Pesantren Al Mukmin Ngruki; Islam, Militancy and the Quest for Identity in Post-New Order Indonesia.: Zainudin Fanani dalam penelitiannya "Radikalisme Keagamaan dan Perubahan Sosial di Surakarta; dan Noorhaidi Hasan dengan penelitiannya yang berjudul Laskar Jihad: 


\section{METODE PENELITIAN}

Penelitian ini menggunakan pendekatannya sosiologi agama (P. Connolly, 2002: 267) dengan metode kualitatif-deskriptif, artinya peneliti mencari deskripsi yang menyeluruh, mendalam, dan cermat tentang corak keberagamaan Jamuro. Sedangkan penyampaian secara deskriptif diharapkan mampu menggambarkan relasi sosial Majelis Mujahidin dalam Konstelasi kebangsaan di Yogyakarta (Saidi, Anas, 2006: 45). Fokus penelitian pada Majelis Mujahidin Pusat, yang dilakukan antara bulan Januari sampai Maret 2016, dengan teknik pengumpulan data melalui tiga cara, yaitu: wawancara mendalam, observasi terlibat, dan teknik dokumentasi. Sedangkan teknik analisis data yang digunakan adalah model analisis interaktif yang meliputi tiga tahapan, mulai dari reduksi data, penyampaian data, dan penarikan kesimpulan (Suprayogo, Imam, 2003: 192-196). Selanjutnya, peneliti melakukan uji validitas data dengan review informan.

\section{PEMBAHASAN \\ Mengenal Majelis Mujahidin Indonesia Awal Kelahiran Majelis Mujahidin}

Sejak pemerintahan reformasi Presiden B.J. Habibie, gerakan-gerakan Islam mulai mendapatkan ruang bebas untuk dapat mengartikulasikan kepentingan-kepentingan umat Islam. Meski umurnya masih muda, pengurus MMI mengklaim bahwa kehadiran mereka telah dinantikan oleh umat Islam di Indonesia yang merindukan penerapan syariat Islam dan dengan demikian berkembang cukup cepat. Mereka berupaya untuk menjadi organisasi basis (tansiq) bagi organisasi, kelompok atau individual muslim yang mempunyai orientasi dan metode gerakan yang sama untuk memperjuangkan penerapan syariat Islam di Indonesia. Mereka mengklaim telah mempunyai perwakilan di 8 provinsi di Indonesia yang meliputi Sumatera Selatan, Sumatera Utara, Jakarta, Yogyakarta, Jawa Barat, Jawa Timur, Bali dan Nusa Tenggara Barat.

Ada tiga situasi yang mendorong dan melatarbelakangi diadakan kongres I Mujahidin Indonesia yaitu alasan historis, syar'iyah dan alasan situasional. Secara historis bahwa perjalanan Islam pertama-tama diperjuangkan kelompok dan kelompok itu tidak sektarian artinya terbuka. MM meramu dimana ada kelompok masjid sehingga tema pada saat itu penegakan syari'ah Islam. Penegakan
Syari'ah Islam dari jaman Gus Dur sampai Jokowi tidak berubah. Gus Dur saja menerima penegakan syariah Islam, persoalannya setelah koma (') itu apa? MM tidak alergi dengan siapapun yang berbeda. Jadi, MM tidak ada beban menghadapi siapa saja (Shabbarin Syakur, wawancara, 24/02/2016).

Secara syar'iyah, bahwa menegakkan syariah bukan kewajiban orang per orang tetapi kewajiban bersama. Bagaimana orang berjamaah kalau tidak ada jamaah. Sehingga menegakkan syariat Islam menjadi ikon masing-masing pribadi. Belum ada orang Islam yang menolak syariah Islam. Situasional (Pasca Reformasi), semua berlombalomba menyuarakan, ada PSK demo, LGBT, saat itu banyak partai Islam berdiri. Apa bisa Islam akan jaya dengan partai-partai itu. Setelah dialog, ternyata partai-partai itu mempunyai tujuan sendiri-sendiri. Sehingga diperoleh kesimpulan bahwa Islam akan jaya kalau di bawah ulama, Artinya dengan ilmu keulamaan Islam akan jaya. Sehingga para pemuda masjid yang tergabung dalam koordinator pemuda masjid mencetuskan ide mengadakan suatu konggres yang kemudian sekarang kenal dengan Konggres Mujahidin (Shabbarin Syakur, Sekretaris Umum Lajnah Tanfidziyah MM, 24/02/2016)

Kongres Mujahidin I ini dihadiri oleh lebih dari 1800 peserta dari 24 provinsi, berlangsung selama 3 hari pada tanggal 5-7 Agustus 2000. Sebutan "Majelis Mujahidin" mengacu pada lembaga yang dibentuk dalam kongres Mujahidin I, sebagai wadah yang terdiri dari sejumlah tokoh Islam Indonesia yang disebut sebagai Ahlul Halli wal Aqdi (AHWA) yang mengemban amanat untuk meneruskan misi penegakan syariat Islam.

Para pencetus kongres tidak tahu apa yang akan dihasilkan pada konggres mujahidin. Bagi para pemuda masjid saat itu yang penting dapat mengadakan konggres mengenai hasilnya biarlah mereka yang membicarakan. Hal ini dikatakan sebagaimana petikan sebagai berikut:

"Akhirnya Deklarasi Kongres Mujahidin
menyepakati membentuk Majelis namanya
Majelis Mujahidin Indonesia sifatnya aliansi
dari berbagai kelompok. Kita tidak tahu kalau
akhirnya akan muncul nama ini. Sehingga
saat itu banyak Majelis Mujahidin. Di Jawa
Timur Majelis Mujahidin Indonesia dikuasai
orang NU, di Jawa Barat MMI dikuasai orang
Muhammadiyah, dan lain-lain". (Shabbarin
Syakur, Sekretaris Umum Tanfidziyah MM,
24/02/2016).




\section{Proses terpilihnya AHWA dan Lajnah Tanfidz pertama kali}

Proses pemilihan Amir Majelis Mujahidin dapat digambarkan seperti petikan pernyataan Shabbarin Syakur, pada tanggal 24 Pebruari 2016 sebagai berikut:

"Kongres memilih 36 orang tokoh duduk dalam Ahlul Halli Wal Aqdi (AHWA) kemudian diperkenalkan kepada peserta. AHWA kemudian memilih salah satu untuk dijadikan AMIR dan saat itu terpilih Ust. Abu Bakar Basyir. Beliau sudah terkenal saat itu meskipun belum setenar sekarang. Adapun nama AHWA yang terpilih 36 orang diantaranya: KH. Ali Yafie, Prof. Dr. Ahmad mansyur Suryanegara, Prof. Dr. Deliar Noor, KH. Mawardi Noor, Ohan sudjana, SH., KH. Abdullah Rasyid, KH. Asep Mausul Afandi, Kh. SiddiqAmin, KH. Miftah Farid, Ust. Abu Bakar ba’asyir, Ust. Muhammad Thalib, KH. Kamaluddin Iskandar, KH. Alayy Muhammad, Ust. Abdul Qodir Baraja. Baharuddin Anwar, KH. Salman Farid, Tengku H. Daud Zamzani. Tengku H. Ibtahim Bardan, Prof. Dr. Abdulrafham A. Basalam dan Ust. Zamzan".

Terpilihnya Ust. Abu Bakar Basyir merupakan kesepakatan dalam diskusi anggota AHWA artinya bukan direncanakan sebelumnya. Hal ini dikarenakan Panitia dan peserta kongres belum mempertemukan tokoh guna membahasnya sebelum konggres berlangsung bahkan beberapa tokoh baru pertama bersilaturrahim saat pelaksanaan kongres ini.

Suasana setelah terpilihnya AMIR oleh anggota AHWA dan terpilihnya ketua tanfidz seperti gambaran berikut:

"Pada saat pidato terpilihnya tanpa di duga dia mengatakan bahwa beliau menjadi amir untuk sementara sampai ada amir definitif. Saat itu panitia heran bagaimana amir bisa begitu. Satu tahun kemudian, 2001 AHWA mudzakarah/rakernas di Ciputat Jakarta. Sebelum rakernas beliau menyatakan akan mundur kepada para penggagas konggres. Para pemuda keberatan sehingga tidak jadi mundur. Saat AHWA bersidang untuk memilih ketua Tanfidziyah terjadi deedlock sehingga ada yang mengatakan dikembalikan ke panitia. Akhirnya, Ketua dan sekeretris panitia kongres dipilih menjadi ketua Tanfidyah dan sekretaris (Shabbarin Syakur, Sekretaris Umum Tanfidziyah MM, 24/02/2016).

Pernyataan ini lebih menjelaskan bahwa sebenarnya kepemimpinan Abu Bakar Basyir sudah ada tanda-tanda tidak sejalan sejak awal terpilihnya. Pada kongres II di Solo tahun 2003 Ust. Abu Bakar dipilih kembali dan saat itu sudah keluar masuk penjara. Permasalahan hukum yang meninmpanya menjadikan tidak konsentnya ust Abu Bakar Basyir dalam menjalankan roda Majelis Mujahidin. Pergantian Amir Majelis Mujahidin dilakukan pada kongress Mujahidin III tahun 2008 sekaligus pembacaan surat pengunduran diri sebagaimana yang sudah dipersiapkan dan ditandatangi pada saat rapat AHWA sebelumnya pelaksanaan kongres.

\section{Karakteristik Perjuangan}

Dalam karakteristik perjuangan, ada 5 (lima) karakteristik Majelis Mujahidin yang menjadi landasan para mujahid penegak Syari'at Islam, dalam mengayunkan langkah perjuangan menegakkan Syari'ah Islam, yaitu (1) Persaudaraan Berasas Aqidah Tauhid; (2) Berterus Terang dengan Kebenaran; (3) Kesediaan Berkorban Jiwa dan Harta di Jalan Allah; (\$) Disiplin Menjalankan Dakwah dan Jihad, meliputi disiplin Shaf (institusi), disiplin dalam Tugas, disiplin menjalankan Aturan dan disiplin melaksanakan Program; dan (5) Komitmen dan 1stiqamah Menegakkan Syari'ah Islam

\section{Aqidah, Visi dan Misi}

Majelis Mujahidin yang markas pusat beralamat di Jl. Karanglo No. 94 Kotagede Yogyakarta. Amanah Penegakan Syaria'ah Islam oleh Majelis Mujahidin dilandasi ajaran Tauhid yang utuh, sebagaimana yang dituntunkan oleh Rasululullah saw sesuai dengan pemahaman para shahabat/ulama salafus shalih (Majelis Mujahidin, 2013: 39). Sedangkan Visi Majelis Mujahidin adalah tegaknya Syariat Islam secara kaffah dalam kehidupan umat Islam.

Adapun misi Majelis Mujahidin dalam mengkonkritkan visi adalah berjuang lillahi tảala demi tegaknya syariat Islam secara menyeluruh dalam segala aspek kehidupan; pribadi dan keluarga, bangsa dan negara. Sehingga masyarakat memperoleh keberuntungan hidup dunia dan akhirat serta membawa rahmat bagi rakyat, negara, dan alam semesta (Majelis Mujahidin, 2013: 39). 
Ini sesuai dengan Grand desain kongres Mujahidin I seperti dalam petikan wawancara dengan Harun al Sarjono, pengurus Majelis Mujahidin bidang HAM (Hubungan Antar Mujahid) sebagai berikut:

"Grand Desain Kongres I Tahun 2000 di Yogyakarta adalah UUD " 45 yang sesuai syariah, hukum pidana sesuai Syariah, bernegara menurut Syariah dan embangun Perekonomian Umat menurut Syariah" (Harun al Sarjono, HAM MM, 02/02/2016).

Tema besar kongres Mujahidin I dirumuskan dalam rincian antara lain: kekuatan pemerintahan berada di tangan kaum muslimin yang jelas komitmennya dalam menegakkan Syari’ah Islam; Kebijakan negara harus sesuai dengan hukum yang digariskan Allah swt, dalam mengatur kehidupan sosial kemasyarakatan; dan Peradaban manusia dibangun di atas peradaban (budaya) yang sesuai dengan akhlak Islam.

\section{Strategi Dasar Majelis Mujahidin}

Operasionalisasi dari pendekatan struktural meliputi kegiatan utama, yakni: (1) Membangun dan melakukan konsolidasi, kristalisasi serta pembinaan pada kekuatan sosial politik yang ada untuk tegaknya Syari'ah Islam. Dan (2) Mengembangkan kemampuan tansiq dalam memberi arahan sosial sesuai dengan Syariah Islam pada pemerintahan yang sedang berjalan (Majelis Mujahidin, 2013: 39).

Adapun terkait dengan kegiatan pertama maka strategi perjuangan Majelis Mujahidin ditekankan pada (a) Menyiapkan serta memantapkan konsep pengelolaan pemerintahan yang sesuai dengan Syari'ah Islam dalam semua bidang kehidupan' (b) Mengajak secara proaktif semua kekuatan sosial politik untuk memahami akan esensi terjadinya berbagai krisis multi dimensional di dalam negeri; dan meyakinkan mereka bahwa solusi mendasarnya tidak bisa lain kecuali dengan tegaknya Syariah Islam dalam lingkup sosial kenegaraan, (c) Menjadikan Majelis Mujahidin sebagai fasilitator semua kekuatan sosial politik yang sejalan dengan Misi Majelis dalam melaksanakan strategi dasarnya untuk penegakan Syariah Islam.

Sedangkan terkait dengan kegiatan kedua ini, maka kegiatan Majelis Mujahidin meliputi: (a) Konsolidasi organisasi Majelis Mujahidin dari tingkat Pusat sampai ke perwakilan di daerah agar semua organ majelis hidup menjalankan Misi majelis, (b) Intensif melakukan kaderisasi untuk meneruskan estafeta kepemimpinan Majelis' dan (b) Menggalang simpati dan kekuatan media massa supaya ikut andil dalam sosialisasi penegakan Syariah Islam.

Dalam menjalankan strategi perjuangan Majelis Mujahidin tidak mengadopsi tokoh dan ulama siapapun akan tetapa mengambil yang sesuai Al Qur'an dan Sunah sebagaimana di contohkan Rasulullah saw (Harun al Sarjono, komisi HAM Majelis Mujahidin, wawancara 02/02/2016).

\section{Keanggotaan Majelis Mujahidin}

Setiap Muslim dan Muslimah yang berada di berbagai orpol, ormas, harakah, jama'ah Islam maupun lainnya yang setuju dengan Syariah Islam secara kaffah dalam kehidupan pribadi, keluarga, masyarakat dan negaranya, dan sepahan dengan misi Majelis Mujahidin, bisa menjadi anggota Majelis Mujahidin.

\section{Manhaj Perjuangan}

Manhaj perjuangan Majelis Mujahidin adalah Dakwah dan Jihad Fii Sabilillah

Dakwah, artinya usaha untuk menjelaskan hakekat dienul Islam, terutama kewajiban menegakkan Syariah-Nya. Jihad Fii Sabililla adalah berjuang dengan semangat tinggi untuk membela Islam, dan ksediaan untuk mengorbankan harta dan jiwa raga guna menghadapi segala bentuk tantangan fisik maupun non fisik dalam rangka melindungi dakwah dan mengawal tegaknya Syariah Islam. (Majelis Mujahidin, 2013: 42-43).

Majelis Mujahidin menghindarkan diri dari kesan sebagai sebuah firqah baru di hadapan kelompok-kelompok perjuangan dalam tubuh kaum muslimin itu sendiri, yang justru akan menambah lemahnya barisan Islam yang kini sudah sangat lemah. Untuk itu Majelis Mujahidin harus memposisikan diri secara benar sehingga keberadaannya benar-benar dirasakan sebagai kekuatan fasilitator bagi segenap kelompok muslimin untuk kembalai kepada satu shaf barisan kaum muslimin. (Majelis Mujahidin, 2013: 46-47)

Dalam mengembalikan dan menegakkan kembali tatanan kehidupan umat Islam, parpol dan ormas Islam pernah menempuh berbagai langkah antara lain:

Pertama, perjuangan parlemen sehingga didirikanlah partai-partai Islam yang bersaing dengan partai sekuler dalam upaya mengisi kursi parlemen di suatu negara tempat kaum muslilimin hidup. Kedua, gerakan pembinaan aqidah,a khlak, pendidikan, sosial dan ekonomi tanpa mau terlibat sedikit pun dalam urursan perjuangan politik. 
Gerakan ini lebih mengutamakan pendekatan akhlak individual, keluarga dan masyarakat. Usaha yang dilakukan melalui lembaga-lembaga pendidikan formal atau non formal, pengajian, dan kursus-kursus keagamaan lainnya. Ketiga, gerakan bersenjata, yaitu melakukan perjuangan bersenjata dan perebutan kekuasaan dari penguasa sekuler yang menguasai negeri-negeri Islam. Keempat, gerakan budaya, yaitu membaur ke dalam masyarakat dari sistem kemasyarakatan yang ada sambil memperbaikinya dan menanamkan nilainilai Islam sejauh yang dapat diterima masyarakat. Kelima, yaitu Uzlah, menarik diri dari semua macam gerakan di atas dan hanya mengurus serta menyelamatkan diri sendiri sambil memperbaiki dan menanamkan nilai-nilai Islam sejauh yang dapat diterima oleh mayarakat. (MM, 2013: 47-48).

\section{Kongres Majelis Mujahidin}

Kongres Majelis Mujahidin ini diadakan 5 tahun sekali. Peserta kongres adalah semua anggota Majelis Mujahidin yang telah terdaftar secara resmi di kantor Pusat Majelis Mujahidin. Anggota yang bersifat kelompok diwakili oleh Pengurus Harian kelompok tersebut.

Badan tertinggi Majelis Mujahidin adalah Kongres Mujahidin yang diselenggarakan setidaktidaknya 5 tahun sekali, dengan dihadiri oleh aktivis Islam (mujahidin) yang tergabung dalam wadah Majelis Mujahidin.

Pimpinan Ahlul Halli Wal Aqdi (AHWA) Majelis Mujahidin periode 1434-1439 H/2013-2018 $\mathrm{M}$ adalah sebagai berikut: Drs. Muhammad Thalib (Amir), Abu Muhammad Jibriel AR (Wakil Amir I), H. Jel Fathullah Al-Anshari, Lc. (Wakil Amir II), Djokotrisno Widodo, SH (Wakil Amir III), Drs. Nashruddin Salim, SH, MH (Katib 'Aam), Drs. Farid Ma'ruf NS (Wakil Katib 'Aam), Drs. Harun Rasyid, Sp BU. MARS (Baitul Maal) dan Dr. H. Irfianda Abidin, SE. MBA (Wakil Baitul Maal). Alat kelengkapan meliputi komisi-komisi: Hukum dan Fatwa, Pendidikan dan Dakwah dan Siyasah.

Sedangkan Lajnah Tanfidziyah terdiri dari Irfan S. Awwas (Ketua Umum), Dr. Amran Zaenuddin (Ketua I), Arfan M. Alwy, M.Ag., (Ketua II ), Drs. H. La Ode Agus Salim, MM (Ketua III), M. Shabbarin Syakur (Sekretaris Umum), Muhammad Rusmadi, M.Ag (Sekretaris I), Drs. Tofandi (Bendahara Umum) dan HM. Sholichin (Bendahara I). Alat kelengkapan terdiri atas Departemen Hubungan dan Komunikasi Antar Mujahid, Askariyah, Pendidikan dan Kaderisasi SDM,
Data dan informasi, Siyasah Syar'iyah, Dakwah dan Tarbiyah, Ekonomi dan Keuangan, An-Nisa' Mujahidah dan Non Departemen meliputi Litbang dan Advokasi Hukum dan Perundang-undangan (Majelis Mujahidin, 2013: 93-96)

\section{Majelis Mujahidin Dalam Kehidupan Masyarakat Mengakses layanan pemerintah}

Majelis Mujahidin tidak mempersoalkan hidup di negara mana saja karena itu sesuai dengan kehidupan pada masa Rasulullah saw. Penegakkan Syariah Islam akan yang diperjuangkan akan terwujud dalam suatu komunitas keluarga, masyarakat, bangsa dan negara. Sehingga keberadaan Majelis Mujahidin dalam keanggotaan Majelis Ulama Indonesia (MUI) Daerah Istimewa Yogyakarta tidak mengherankan. Meskipun dalam perjalanannya saat ini MM jarang dilibatkan dalam rapat-rapat yang diadadakan oleh MUI sendiri (Nizar, Kakanwil Kemenag DIY, 01/02/2016).

Secara administratif, anggota Majelis Mujahidin juga mengurus keperluan pencatatan kependudukan pada lembaga negara yang ada sebagaimana masyarakat pada umumnya. Seperti KTP di kelurahan dan pencatatan Nikah di KUA (Nuraini, Baturetno, 07/03/2016). Hal ini seperti petikan berikut ini:

\begin{abstract}
"Dengan pemerintah termasuk Kementerian Agama mereka juga mau bergaul hanya saja personil kementerian Agama saja yang kurang merangkul mereka. Saya pernah mengundang ormas-ormas untuk berdialog dan berinteraksi dalam forum kerukunan. Mereka juga berkenan hadir seperti pada umumnya" (Maryadi, Penyuluh Agama Kec. Banguntapan Bantul, 07/03/2016).
\end{abstract}

Hanya saja, kelompok keagamaan Majelis Mujahidin memang belum didaftarkan sebagai organisasi kemasyarakatan baik di lembaga pemerintah propinsi maupun kementerian agama dengan alasan hanya perkumpulan biasa karena sfatnya tansiq atau aliansi (Shabbarin Syakur, Sekjen MM, 24/02/2016).

Pemerintah dalam hal ini kementerian Agama tidak dapat campur tangan ke dalam tubuh kelompok keagamaan sepanjang belum terdaftar, seperti yang disampaikan pejabat Kemenag berikut:

"Sepanjang tidak terdaftar di Kementerian Agama kita tidak dapat memantau atau membina. Masalahnya, regulasi tidak 
mengamanatkan kewajiban mendaftarkan dirinya. Sehingga tidak ada paksaan dalam pembinaannya. Kalaupun mendaftar hanya mencari legalitas semata. Namun, masih belum mau mengakses program pemerintah seperti Pondok Pesantren di Sleman" (Nizar dan Rohwan, Kanwil Kemenag DIY, 01/02/2016).

\section{Relasi dengan tokoh dan kelompok keagamaan lainnya}

Majelis Mujahidin mengidealkan seluruh kaum muslimin bersatu sebagaima perintah $\mathrm{Al}$ quran. Penegakan syariah Islam dalam suatu lembaga negara tidak dapat berjalan sebagaimana diingingkan apabila umat Islam sendiri tidak bersatu padu. Oleh karena itu, Majelis Mujahidin selalu terbuka berdialog dengan kelompok agama manapun baik yang dalam berjuang menggunakan cara turun langsung ke sasaran sampai yang berjuang melalui jalan lainnya. Pada intinya Majelis Mujahidin selalu siap bekerja sama dengan kelompok manapun (Irfan S Awwas, Ketua Tanfidz, 28/02/2016).

Majelis Mujahidin beberapa kali mengadakan kegiatan di Masjid Jl. Jogokaryan Kota Jogja. Peserta melibatkan umum artinya kelompok keagamaan manapun dipersilakan mengikuti kajian yang diadakan oleh Majelis Mujahidin (Ahmad M, Warga Jl. Taman Siswa, 02/03/2016).

Ukhuwah dan jalinan silaturrahim juga terjalin antara Majelis Mujahidin dengan tokoh kelompok keagamaan lainnya. Kajian Ahad pagi yang merupakan kajian rutin kerap kali menghadirkan tokoh atau pimpinan kelompok keagamaan lain. Pada kajian Ahad pagi tanggal 31 Januari 2016 yang menjadi pembicara adalah Ust. Puji Hartono, seorang Motivator dari Fron Jihad Islam (FJI) Yogyakarta. (Harun al sarjono, Departemen HAM Majelis Mujahidin, 02/02/2016).

Pada kesempatan kajian Ahad pagi lainnya diisi oleh pembicara Ust. Umar Said Dewan Syuro FJI Yogyakarta (Observasi, Kajian ahad pagi, tgl 6 Maret 2016). Hal ini sesuai dengan yang disampaikan oleh Wakil Amir Majelis Mujahidin, Ust. Abu Jibril Muhammad, bahwa anggota Majelis Mujahidin hendaknya belajar dan mencari ilmu di mana saja pada siapa saja dalam upaya penegakkan syariah Islam (Kajian Ahad pagi, observasi tanggal 28 Pebruari 2016)

\section{Pandangan dan sikap masyarakat terhadap Majelis Mujahidin}

Aktifitas pendukung penegakkan Syariah Islam yang tergabung dalam Majelis Mujahidin dalam pandangan masyarakat Yogja tidak mempunyai rekor yang mencolok. Hal ini dikarenakan program dan kegiatan banyak menyentuh kebutuhan masyarakat pada umumnya. Ketika Yogja di guncang gempa Korps Relawan Mujahidin (KRM) bergerak cepat bahkan menjadikan Markaz Pusat sebagai posko bagi pengungsi korbang bencana. Begitu juga saat terjadi Tsunami di Aceh akhir tahun 2014 Majelis Mujahidin pun segera membuka posko dan mengirim personil ke lokasi bencana (Harun al Sarjono, wawancara, 02/03/2016 dan Abbas, 07/03/2016).

Upaya menolong dalam suatu bencana yang dimotori Majelis Mujahidin merupakan perwujudan tolong menolong dalam kebaikan dan tidak tolong menolonga dalam keburukan seperti yang diperintahkan Allah (QS. Al-Maidah: 2). Hal Ini juga salah satu upaya penegakkan syariah sesuai tuntunan nabi Muhammad saw.

Adapun pandangan masyarakat sekitar terkait Majelis Mijahidin dapat di simak dari penuturan seorang informan berikut:

"Majelis Mujahidin Indonesia mempunyai kegiatan yang baik, yang positif, seperti kursus bahasa Arab, pesantren kilat. Informasi biasanya melalui papan informasi masjid. Tidak ada kesan radikal sama sekali. Saya juga belum pernah mendengar MMI berbuat anarkis" (Agus, Kotagede, 29/02/2016)

Majelis Mujahidin merupakan salah satu Kelompok keagamaan di Daerah Istimewa Yogjakarta. Mereka mempunyai garis perjuangan sendiri dan cara sendiri-sendiri. Hal ini dikonfirmasi oleh Informan lain bahwa dia mempunyai tetangga yang kebetulan anggota MMI. Dalam pergaulan sehari-hari dengan tetangga dan lingkungan biasa saja. Tidak ada kesan eksklusif. Pada suatu kesempatan mengajak agar masyarakat menegakkan syariaat sebagaimana yang dibawa Rasulullah saw. Untuk radius lingkup kota Yogja MMI tidak ada kesan negatif apalagi tingkat kecamaran. Tetapi dia tidak tahu kalau di luar kota Joga. (A. Mustafid, Kepala KUA Kec. Kotagede, 01/03/2016).

Beberapa informan yang tinggal di sekitar Markaz Pusat Majelis Mujahidin ketika di tanya seputar kiprah anggota MM dalam kehidupan 
masyarakat sependapat bahwa tidak ada yang merugikan masyarakat sekelilingnya dalam berinteraksi. Hal ini seperti apa yang dikatakan informan berikut:

"Dalam pergaulan sehari-hari anggota Majelis Mujahidin tidak tampak eksklusif. Tidak jauh dari rumah ada anggota yang membuka praktek pengobatan herbal. Setiap hari masyarakat umum banyak yang datang memanfaatkan jasanya. Masyarakat juga tidak segan-segan lagi bergaul dengan anggota Majelis Mujahidin yang bersikap seperti masyarakat pada umumnya. Banyak diantara mereka yang masuk kategori orang kaya sehingga tidak heran Majelis Mujahidin mempunyai Markaz Pusat yang cukup besar." (Nuraini, Baturetno, Banguntapan Bantul, 07/03/2016).

Penegakkan syariah Islam mencontoh kehidupan Rasulullah saw dimulai dari diri sendiri, keluarga dan masyarakat pada umumnya. Hal ini selalu diserukan para pengurus Majelis Mujaidin sebisa mungkin dipraktekkan para anggota Majelis Mujahidin dalam hidup sehari-hari. Ketika tiba waktu Shalat Magrib maka segera bergegas pergi ke masjid dengan meminta maaf bukan berarti menghendaki tamu untuk pulang tetapi menawarkan nanti dapat dilanjutkan kembali (observasi aktifitas Abbas, 07/03/2016).

\section{Pandangan Sikap Majelis Mujahidin Dalam Konstelasi Kebangsaan \\ Pandangan Majelis Mujahidin terkait NKRI}

Ketika Nabi Muhammad saw mengijinkan para sahabatnya hijrah ke Habasyah (Ethiopia), di bawah kekuasaan Raja Najasyi (Negus) yang beragama Nasrani. Tidak ada yang mempersoalkan, apakah Habasyah negeri Thaghut atau negara Kristen. Bahkan kaum Muslimin mendapatkan suaka politik, dilindungi dari ancaman kafir Quraisy. Begitupun, ketika Rasulullah shallallahu 'alaihi wasallam hijrah ke Yastrib, sebelum bernama Madinah, tidak ada orang Islam yang bertanya, apakah Yastrib wilayah Thaghut atau bukan. Bahkan Nabi saw sendiri tidak pernah mengklaim status wilayah yang akan menjadi tujuan hijrahnya itu. (Dialog Majelis Mujahidin dengan Wantimpres, 6 Maret 2014 dan wawancara dengan Irfan S Awwas, 03/02/2016).

Hal ini memperjelas bahwa keberadaan suatu wilayah atau negara merupakan hal yang pokok atau mutlak dalam pelaksanaan syariah Islam. Secara lugas, Abbas, Ketua LPW MM Yogjakarta mengatakan:

"Kami tidak menolak negaranya. Memang kita hidup dalam suatu wilayah negara. Yang kita lihat apakah produk aturan itu sesuai apa tidak dengan syariat Islam. Kalau sesuai kita terima laksanakan dan kalau tidak kita tolak " (Abas, Ketua LPW Majelis Mujahidin Yogyakarta, 07/03/2016).

Sikap inilah yang secara terus terang disampaikan Majelis Mujahidin kepada masyarakat dan lembaga negara dalam perjuangannya. Sehingga Majelis Mujahidin menyadari betul di pihak lain ada yang mengatakan sebagai lembaga keagamaan yang radikal. Namun, pengertian dan kriteria radikal masih didasarkan pada asumsi dan pendapat perorangan sehingga sangat dimungkinkan ada kepentingan pihak tertentu, seperti secara lugas terekam pada petikan:

"Mengenai radikal Kemenag harus punya format sendiri. Apa berdasarkan pemahaman, perilaku. Sama kalau definisi kelompok harus beradasarkan keyakinan bukan beradasarkan HAM. Maka Kemenag buatlah kriteria nanti kita diskusikan, Kemenag harus punya posisi jangan seperti selama ini kenapa berpegang kepada kafir-kafir itu, kenapa berpegang pada Syiah". (Irfan S Awwas, Ketua Umum Tanfidziyah MM, 03/02/2016).

Dalam perjuangannya Majelis Mujahidin menggunakan cara-cara konstruktif dan tidak asal mengeluarkan pendapat tanpa dasar yang kuat. Segala sikap dan pandangan sudah melalui kajian mendalam dan diberikan berbagai alternatif solusi pemecahan problemnya.

"Banyak upaya meluruskan pemahaman misalnya melalui diskusi. Sebelum ramai berita ISIS MMI sudah menolak lebih dulu. Majelis Mujahidin tidak sembarangan bahkan sudah mengoreksi Alquran terjemahan Kemenag dengan terjemahan tafsiriyah." (Irfan S Awwas, Ketua Umum Lajnah Tanfidziyah MM, 03/02/2016).

Pelurusan pemahaman Syariat Islam oleh majelis Mujahidin banyak dilakukan dengan dialog dan diskusi. Koreksi fenomenal Majelis Mujahidin adalah ketika mengoreksi 3229 ayat dalam Alquran Kementerian Agama yang salah terjemah. Bahkan 
ada yang dapat mengantarkan orang awam berbuat radikal ketika membaca Alquran. Majelis Mujahidin berdialog dan beraudiensi menyampaikan koreksinya dengan pihak-pihak terkait termasuk dengan Kementerian Agama RI. Pada akhirnya Majelis Mujahidin menerbitkan Alquran terjemah tafsiriyah tidak seperti Alquran terjemahan harfiahnya Kementerian Agama. Koreksi Alquran tafsiriyah terhadap Alquran tarjamah harfiyah Kementerian Agama merupakan komitmen Majelis Mujahidin membawa masyarakat memahami Alquran dengan baik dalam kehidupan diantaranya hidup berbangsa dan bernegara.

Pemahaman Majelis Mujahidin sangat bertentangan dengan ISIS yang saat ini ramai dibicarakan. Salah satunya dalam menerjemahkan harta $f a^{\prime} i$ ketika ditanyakan bagaimana pandangannya yaitu:

"Harta yang di dapat karena kalah dalam perang itu Rasulullah dapat 20 persen dari harta tetapi kalau $f a^{\prime} i$ musuh menyerah maka pasukan tidak mendapat bagian tetapi semua masuk ke kas negara. Pasukan dapat bagian dari negara yang mengatur" (Muhammad Thalib, Amir Majelis Mujahidin, 27/02/2016).

Hal itu berlaku apabila kondisi negara dalam keadaan terjadi peperangan. Pada saat negara aman seperti sekarang tidak bisa melakukan perampasan seperti pemahaman kelompok lain. Oleh karena itu, Majelis Mujahidin tidak sepaham dan menentang aksi pengeboman dan teror yang dilakukan sebagian orang tertentu lebih-lebih yang dilakukan di tempat ibadah.

Dalam suatu kesempatan Majelis Mujahidin mempertanyakan, apakah penegakan syariah bisa dikatakan radikal? Menurutnya, Majelis Mujahidin pelanjut dari dasar negara yang asli dan tidak merasa melanggar kembali kepada dasar negara ketuhanan. Negara berdasar atas ketuhanan Yang Maha Esa. Sehingga dipertanyakan pada bagian mana Pancasila dikatakan menjadi dasar negara? (Irfan S Awwas, Ketua Umum Lajnah Tanfidziyah MM, 03/02/2016 dan Muhammad Thalib, Amir MM, 27/02/2016).

\section{Pandangan Majelis Mujahidin terkait Demokrasi}

Dalam Undang-Undang Dasar tidak menyebutkan demokrasi secara jelas dan bukan merupakan produk bangsa Indonesia. Muhammad Thalib, Amir Majelis Mujahidin mengatakan bahwa tidak ada kata-kata demokrasi dalam UUD, seperti petikan berikut:

"Ada nggak kata-kata demokrasi dalam UUD. Permusyawaratan tidak sama dengan demokrasi. Kekuasaan di tangan rakyat dan dilakukan sepenuhnya oleh Majelis Permusyaratan rakyat. Padahal setelah amandemen UUD 45 presiden tidak lagi bertanggung jawab kepada MPR. Semua lembaga sejajarjaditidakadayang mengontrol. Jadi yang benar presiden bertanggung jawab kepada MPR" (Muhammad Thalib, Amir Majelis Mujahidin, 27/02/2016).

Lembaga-lembaga negara yang kedudukannya sejajar tidak dibenarkan karena tidak ada yang mengontrol. Selain itu, kekuasaan rakyat tidak lagi mempunyai kekuasaan tertinggi yang diwujudkan dalam Majelis Permusyawaratan Rakyat (MPR) dimana Presiden mempertanggungjawabkan amanahnya pada akhir masa jabatan.

Ketika ditanya apakah tidak sebaiknya berjuang melalui parlemen dengan ikut mencalonkan diri menjadi anggota DPR sehingga segera terwujud penegakkan Syariah Islam mereka mengatakan bahwa banyak orang-orang aktifis yang masuk ke partai dan duduk sebagai wakil rakyat namun kenyataannya mereka tidak dapat berbuat apa pun akan tetapi malah ikut hanyut dalam sistem dan melakukan pelanggaran (Muhammad Thalib (27/2/2016), Shabbarin Syakur (24/2/2016) dan Harun al sarjono (2/2/2016).

Adapun sikap Majelis Mujahidin saat pemilihan umum menyerahkan sepenuhnya kepada anggota sedangkan Amir Majelis Mujahidin tidak mengeluarkan Fatwa larangan atau perintah untuk menggunakan hak pilih dalam pemilihan umum.

\section{Respon Majelis Mujahidin terhadap pemerintah}

Dalam suatu kesempatan ketika ditanya mengenai respon terhadap pemerintah majelis Mujahidin mengatakan bahwa yang kita lihat adalah apakah perintah atau aturan yang dikeluarkan sesuai atau tidak dengan syariat Islam (Abbas, Ketua LPW MM Yogyakarta, 07/03/2016). Ketika diwajibkan menghormat apa urgensinya? Tetapi tidak melarang anggota untuk tidak menghormat bendera sehingga anggota sendiri yang memutuskan perlu atau tidaknya. Meskipun demikian bukan berarti menghina lambang negara bendera merah putih. 


\section{Pandangan terkait Pancasila Dasar Negara}

Meyakini Pancasila sebagai dasar negara menunjukkan sikap inkonsisten. TAP MPR XVIII Tahun 1998 mencabut P4 dan menegaskan Pancasila sebagai dasar negara. Sebelumnya TAP MPRS XXV/1966 mencantumkan Pancasila sebagai dasar Negara. Tetapi menurut UUD 1945 ps 29 ayat 1 menyatakan: Negara Indonesia berdasarkan Ketuhanan Yang Maha Esa, bukan berdasarkan Pancasila. Dalam kaitan ini terjadi inkonsistensi dasar negara (Irfan S Awwas, wawancara, 03/02/2016).

Dalam suatu kesempatan ketika dikonfirmasi berkenaan dengan Pancasila dasar negara, Muhammad Thalib, Amir Majelis Mujahidin dengan keras dan lantang mengatakan:

"Orang yang mengatakan negara berdasarkan pancasila itu penyelewengan. Tidak ada yang bantah, itu manipulasi. Itu pengkhianatan kaum nasionalis. Suharto sudah saya tantang sejak tahun 1974 tapi tidak ada bantahan. Indonesia negara Pancasila itu berbohong kepada konstitusi pengkhianatan konstitusi" (Muhammad Thalib, Amir MM, 27/2/2016).

Menurutnya, dasar negara yang sesuai UUD adalah Ketuhanan Yang Maha Esa sebagaimana wawancara berikut ini:

"Negara berdasar atas ketuhanan Yang Maha Esa. Penjelasan yang asli dengan menjalankan syariatnya. Hanya yang dikembangkan oleh nasionalis keluar dari konteks itu. Dalam penjelasan negara yang menjalankan syariat agama. Semua berdasarkan syariat agama. Yang tidak punya syariat yang tidak urus negara. Apa orang kristen punya syariat. Misalnya, UU perkawinan karena di Islam ada syariatnya. Agama lain kan tidak punya syariat perkawinan" (Muhammad Thalib, Amir MM, 27/02/2016).

Jika kita berpegang pada UUD '45, maka negara RI sesungguhnya berdasarkan agama Islam. Sebab istilah Ketuhanan YME adalah konsep Islam, bukan konsep sekularisme, demokrasi, ataupun liberalisme. Ketiga isme ini tidak mengenal Tuhan (Irfan S Awwas, 28/02/2016).

Ketika ditanya adakah kelompok-kelompok anti-Pancasila di Indonesia? Majelis Mujahidin mengatakan bahwa secara obyektif, jangankan
anti-Pancasila, kelompok anti agama bahkan anti-Tuhan juga banyak di Indonesia. Tapi, jika maksudnya yang berkaitan dengan bagaimana mengekspresikan antipati kelompok tersebut baik dengan cara revolusioner ataukah diplomatis, dengan cara radikal atau moderat. Maka menjadi urusan intelijen bukan urusan Majelis Mujahidin (Irfan S Awwas, wawancara 03/02/2016 dan MM dengan Wantimpres, 06/03/2014).

\section{Kedudukan Empat Pilar Negara RI}

Majelis Mujahidin memandang bahwa Empat Pilar Kebangsaan yang saat ini sedang digaungkan adalah hal yang keliru, seperti petikan:

"Empat Pilar kebangsaan nggak betul itu, itu dokrin Nasakom Sukarno. Majelis Mujahidin sudah menyurati MPR, MK, DPR. Tetapi mereka tidak berani dialog (Muhammad Thalib, Amir Majelis Mujahidin, 27/02/2016).

MPR periode 2009-2014 merumuskan Empat Pilar Kebangsaan yaitu: Pancasila, UUD 45, NKRI dan Binneka Tunggal Ika. Keempat pilar ini tidak pernah ada pada ketetapan MPR periode sebelumnya, bahkan juga tidak mempunyai landasan yang sah dari UUD 45. Pada pasal 25A telah disebutkan bahwa Negara Republik Indonesia berbentuk Negara Kesatuan. Jika begitu, Majelis Mujahidin mempertanyakan apa kepentingannya menjadikan NKRI sebagai salah satu pilar Negara Republik Indonesia? (Muhammad Thalib, Amir Majelis Mujahidin, 27/02/2016).

Selama ini Pancasila dianggap sebagai dasar Negara RI, kemudian MPR periode 20092014 menyatakan bahwa Pancasila sebagai salah satu dari pilar Negara. Bukankah keputusan ini bertentangan dengan anggapan umum selama ini? Bukankah hal ini berarti MPR telah merubah kedudukan Pancasila sebagai dasar negara menjadi sekedar pilar negara? Begitu halnya dengan UUD ' 45 yang berkedudukan sebagai hukum dasar bagi negara berubah menjadi sekadar pilar negara. Hal ini menunjukkan adanya kerancuan berpikir dan ketidakmampuan memahami persoalan-persoalan dasar bernegara. Realitas ini sangat membahayakan kehidupan bernegara di masa depan (Dialog MM dengan Wantimpres, 06/03/2014 dalam http:// www.majelismujahidin.com $/ 2014 / 03 / \mathrm{dialog}$ wantimpres-2014-apakah-indonesia-negarathaghut/, dipublikasi 24 Maret 2014 diunduh tgl 18 Pebruari 2016). 


\section{Apakah Indonesia Negara Thaghut?}

Dalam menyikapi kelompok-kelompok kecil yang suka mengafirkan golongan Islam lain di luar kelompoknya, yang di kenal juga dengan kelompok takfiri. Majelis Mujahidin mengatakan sebaiknya mereka diajak berdialog. Sehingga, ketika pada 11 Desember 2013 BNPT menghadirkan ulama dari Mesir DR. Najih Ibrahim dan Hisyam Al-Najjar, dan Ali Hasan Al-Halabi dari Jordania, berdiskusi dengan narapidana teroris di Nusakambangan untuk membuka wawasan warga binaan tentang konsep takfiri dan menyebarkan konsep agama yang damai. Menurut BNPT, terpilihnya ulama yg berasal dari Mesir dan Jordania itu karena mereka memiliki pengalaman dan pemahaman tentang konsep yang diafahami secara sempit oleh kelompok yang cenderung memaksakan kehendak dan merasa diri benar. Majelis mempertanyakan mengapa bukan Wantimpres yang melakukannya? Atau Watimpres juga menganggap mereka musuh yang harus dilenyapkan seperti dilakukan Densus 88? (Irfan S Awwas, 03/02/2016 dan Dialog MM dengan Wantimpres 06/03/2014).

Sedangkan ketika Wantimpres menanyakan bagaimana pendapat Majelis Mujahidin, apakah Indonesia Negara Thaghut atau bukan? Majelis Mujahidin mengatakan bahwa Perdebatan tentang Indonesia Negara Thaghut atau Negara Islam sudah tidak relevan. Fakta sejarah menginformasikan, ketikan Nabi Muhammad shallallahu 'alaihi wasallam mengijinkan para sahabatnya hijrah ke Habasyah (Ethiopia), di bawah kekuasaan Raja Najasyi (Negus) yang beragama Nasrani. Tidak ada yang mempersoalkan, apakah Habasyah negeri Thaghut atau negara Kristen. Bahkan kaum Muslimin mendapatkan suaka politik, dilindungi dari ancaman kafir Quraisy. Begitupun, ketika Rasulullah shallallahu 'alaihi wasallam hijrah ke Yastrib, sebelum bernama Madinah, tidak ada orang Islam yang bertanya, apakah Yastrib wilayah Thaghut atau bukan. Bahkan Nabi saw sendiri tidak pernah mengklaim status wilayah yang akan menjadi tujuan hijrahnya itu.

Adapun formulasi Syariat Islam yang dikehendaki Majelis Mujahidin untuk diakomodasi negara guna menghindari perbedaan internal umat Islam adalah bahwa Majelis Mujahidin Misi Majelis Mujahidin adalah penegakan Syariat Islam di lembaga negara. Sejak awal kemerdekaan, pelaksanaan Syariat Islam sudah merupakan misi negara seperti tercantum dalam UUD ' 45 ps 29 ayat 1 menyebutkan: Negara berdasar atas Ketuhanan Yang Maha Esa. Bahkan Indonesia pernah berdasarkan Syariat Islam, walau sehari, seperti tertulis dalam Piagam Jakarta: "Ketuhanan, dengan kewajiban menjalankan syariat Islam begi pemeluk-pemeluknya, yang kemudian dikhianati kaum nasionalis. Diperkuat lagi dengan keputusan MK No. 19/PUU-VI/2008 tentang Pengujian UU Peradilan Agama terhadap UUD, Mahkamah Konstitusi berpandangan bahwa: "Indonesia adalah negara yang ber-Ketuhanan Yang Maha Esa yang melindungi setiap pemeluk agama untuk melaksanakan ajaran agamanya masing-masing." Maksudnya, tidak boleh ada aturan atau UU yang bertentangan dengan ajaran agama. Jadi, problem di Indonesia bukan model negara mana yang akan diikuti, tapi bangsa Indonesia telah berjanji dalam UUD untuk melaksanakan syariat Islam. Apabila janji ini dipenuhi, niscaya problem kebangsaan akan selesai, dan pertentangan internal maupun antar umat beragama akan dapat diatasi. (Irfan S Awwas, 03/02/2016 dan Dialog MM dengan Wantimpres, 06 Maret 2014).

Pada akhir diskusi dan tanya jawab KH. Ma'ruf Amin, Ketua Dewan Pertimbangan Presiden (Wantimpres) bidang Hubungan Antar Agama, membuat kesimpulan bahwa "Pelaksanaan Syariat Islam tidak bertentangan dengan UUD."

\section{PENUTUP}

Majelis Mujahidin lahir pada tanggal 7 Agustus 2000 merupakan hasil Kongres Mujahidin I di Yogyakarta. Alasan yang mendorong kongres adalah situasi politik pasca reformasi 1998, historis dan alasan Syariah bahwa kehidupan Islam akan tegak berdiri apabila pelaksanaan ilmu agama yang dijadikan landasan kehidupan bermasyarakat dan bernegara Majelis Mujahidin selalu terbuka berdialog dan bekerja sama dengan kelompok agama manapun baik yang dalam berjuang menggunakan cara turun langsung ke sasaran sampai yang berjuang melalui jalan lainnya. Majelis Mujahidin megedepankan konsep dialog dalam mengupayakan penerapan Syariah Islam dalam lembaga negara dan meyakini Penerapan Syariat Islam tidak melanggar UUD. Produk pemikiran Majelis Mujahidin yang disesuaikan dengan syariat Islam sudah dipublikasikan.

Adapun rekomendasi kepada pemerintah cq. Kementerian Agama, Kementerian Dalam Negeri dan terkait lainnya perlu, (1) merespon penegakan 
syariat Islam dalam lembaga negara sebagai bagian aspirasi masyarakat, (2) membangun komunikasi dan menjadikan Majelis Mujahidin sebagai Mitra dalam pembinaan kehidupan berbanggsa bernegara dan kehidupan keagamaan, dan (3) Kementerian Agama diharapkan mempunyai definisi dan kriteria terkait kelompok keagamaan yang dianggap tidak sejalan dengan negara sehingga tidak berdasar stigmatisasi perorangan atau kelompok tertentu yang berkembang di masyarakat.

\section{UCAPAN TERIMA KASIH}

Saya mengucapkan terima kasih kepada keluarga besar Balai Penelitian dan Pengembangan Agama Semarang, Majelis Mujahidin Pusat Yogyakarta, Kakanwil Kemenag DIY dan informan baik saat maupun pasca lapangan yang tidak dapat disebutkan satu per satu. Tidak lupa terima kasih kepada pendamping setia Prihatini Sulistyaningsih (istri), Nazalia Rosadanti Hanan 'Adila, Hanifa Rosadanti Adnani dan Afiif Rosadani Wildan (anak). Juga kepada tim Al-Qalam yang mengapresiasi tulisan ini. Semoga Allah swt membalas semua kebaikannya. Amin

\section{DAFTAR PUSTAKA}

Abegebriel, Agus Maftuh. 2004. Negara Tuhan. The Thematic Encyclopedia. Yogyakarta: SR-Ins Publishing.

Amrullah, Baizar. 2009. Upaya Majelis Mujahidin Memformalisasikan Syariat Islam dalam Lembaga Negar., Yogyakarta: UIN Sunan Kalijaga.

Connolly, Peter. 2002. Approaches to The Study of Religion. Yogyakarta: LKiS.

Imarah, Muhammad. 1999. Fundamentalisme Dalam Perspektif Barat dan Islam, Terj. Abdul Hayyie al-
Kattani. Jakarta: Gema Insani Press.

Irfan S Awwas (penyunting). 2001. Seri Publikasi Risalah Konggres Mujahidin I dan Penegakkan Syariah Islam. Yogyakarta: Wihdah Press.

Kurt, Lester. 1995. God In the global Village. California: Pine Forge Press.

M. Amin Abdullah. 2005. "Kesadaran Multikultural Sebagai Gerakan Interest Minimalization Dalam Meredakan Konflik Sosial", dalam Kata Pengantar Pendidikan Multikultural. Cross Cultural Understanding untuk Demokrasi dan Keadilan. Yogyakarta: Pilar Media.

Majelis Mujahidin. 2013. Pedoman Umum dan Pelaksanaan Majelis Mujahidin Untuk Penegakan Syariat Islam. Yogyakarta: Majelis Mujahidin.

Muin M, Abd, dkk,. 2007. Pendidikan Pesantren dan Potensi Radikalisme. Jakarta: CV. Prasasti.

Rosidin. 2014. "Sufisme Perkotaan dan Nalar Beragama Inklusif" dalam Jurnal Analisa Vol. 21 No. 01 Juni 2014. Semarang: Balai Penelitian dan Pengembangan Agama Semarang.

Saidi, Anas. 2006. Bahan Workshop Pengembangan Penelitian Non-Positivistik Bagi Dosen-Dosen Ptai Se-Indonesia. Wisma Haji Armina Donohudan Boyolali, P3M STAIN Surakarta-Ditjen Binbaga Islam Depag RI.

Suprayogo, Imam dan Tobroni. 2003. Metodologi Penelitian Sosial Agama. Bandung: Remaja Rosdakarya. ..https://majelismujahidin.wordpress. com/2008/01/31/profil-majelis mujahidin/\#more-4, diunduh tanggal 18 Pebruari 2016

.http://www.majelismujahidin. com/2014/03/dialog-wantimpres-2014-apakahindonesia-negara-thaghut/, dipublikasikan pada 24 Maret 2014 diunduh tgl 18 Pebruari 2016 